(C) В.В. Коткова, 2011

ISSN 2076-8184. Інформаційні технології і засоби навчання. 2011. №2 (22).

Режим доступу до журналу: http://www.journal.iitta.gov.ua

УДК 132:004

Коткова Віра Володимирівна, аспірант кафедри педагогіки та психології Херсонського державного університету, м. Херсон

\title{
ПЕДАГОГІЧНІ УМОВИ ФОРМУВАННЯ ІНФОРМАТИЧНИХ КОМПЕТЕНТНОСТЕЙ СТУДЕНТІВ - МАЙБУТНІХ УЧИТЕЛІВ ПОЧАТКОВИХ КЛАСІВ
}

\begin{abstract}
Анотація
Актуальність статті зумовлена сучасною потребою інформаційного суспільства в підготовці інформатично компетентних фахівців початкової освіти. У статті узагальнені педагогічні умови забезпечення процесу формування інформатичних компетентностей студентів на основі сучасних наукових досліджень, визначено місце квазіпрофесійної діяльності студентів у процесі становлення інформатичних компетентностей. Автор статті узагальнює результати анкетування 3 метою дослідження рівня і можливості користування Інтернет студентами, планування i характеру застосування ІКТ під час практики. Серед педагогічних умов формування інформатичних компетентностей майбутніх учителів початкових класів виокремлено квазіпрофесійну діяльність, основними формами реалізації якої $\epsilon$ імітаційне моделювання і педагогічна практика.
\end{abstract}

Ключові слова: інформатичні компетентності, квазіпрофесійна діяльність, етапи інтенсифікації й ідентифікації, контекстне навчання.

Постановка проблеми. Нині учитель перестав бути основним джерелом знань для учнів, які отримують значний обсяг інформації в інформаційно-комунікаційному середовищі, створеному телебаченням, відеофільмами, комп'ютерними програмами й іграми, Інтернет, різноманітною навчальною й науково-популярною літературою тощо. Це вимагає від сучасної вищої професійної освіти підготовки спеціалістів, здатних орієнтуватися у численних змінних потоках інформації, критично ставитись до неї, мати змогу створювати, обробляти й передавати необхідну інформацію, постійно самовдосконалюватись в особистісному і професійному плані до вимог розвитку інформаційного суспільства. Рішенням даної проблеми $є$ професійна підготовка майбутнього вчителя в інформаційно-комунікаційному педагогічному 
середовищі, а саме - формування інформатичних компетентностей.

Аналіз останніх досліджень та публікацій. Проблема компетентнісного підходу в освіті досліджується науковцями (Н. М.Бібік, Л. С. Ващенко, О. І. Локшиною, О.В.Овчарук, Л. І. Паращенко, О. І. Пометун, С. Е. Трубачевою, А. В. Хуторським, Л. Л. Хоружою та ін.), активно вивчається проблема використання інформаційно-комунікаційних технологій (IКT) у навчанні (В. П. Андрущенко, Г. О. Балл, В. Ю. Биков, Р. С. Гуревич, М. І. Жалдак, Ю. І. Машбиць, В. М. Монахов, С. А. Раков, О. В. Співаковський, О. В. Урсова та ін.). Особливостям використання IКТ у професійній підготовці майбутніх учителів початкових класів присвячені роботи В. І. Імбер, А. М. Коломієць, М. М. Левшина, Д. С. Мазохи, Л. Л. Макаренко, Л. Є. Петухової, І. М. Смирнової, Є. М. Смирнової-Трибульскої, О. В. Суховірського, I. М. Шапошнікової, О. І. Шиман та ін.

Виділення невирішених раніше частин загальної проблеми, котрим присвячусться означена стаття. Аналіз наукових досліджень формування компетентностей майбутніх учителів початкових класів у сфері інформаційнокомунікаційних технологій дозволяє виділити суперечності між: потребою освітньої практики у високому рівні інформатичної компетентності сучасних педагогів i невисокою ефективністю процесу професійної підготовки в даному напрямку; існуючими моделями професійної підготовки, спрямованими на формування переважно комп'ютерної грамотності, і необхідністю організації квазіпрофесійної підготовки, орієнтованої на використання IКТ у практичній діяльності.

Формулювання цілей статті (постановка завдання). Основна мета статті дослідити й узагальнити педагогічні умови формування інформатичних компетентностей майбутніх учителів початкових класів, визначених у наукових дослідженнях сучасних науковців, визначити роль і місце квазіпрофесійної діяльності студентів у процесі становлення інформатично компетентного фахівця.

Виклад основного матеріалу дослідження. У сучасній науково-педагогічній літературі зустрічається багато трактувань визначення компетентності вчителів у галузі використання ІКТ: інформаційна компетентність (О. Зайцева, О. Іванова, О. Кизик, О. Нікулочкіна, О. Смолянинова, О. Толстих, С. Трішина, М. Холодна), комп'ютерна компетентність (С. Литвинова), інформаційно-технологічна 
компетентність (П. Беспалов), ІКТ-компетентність (М. Жалдак, А. Єлізаров, О. Овчарук, А. Семенова, О. Урсова, О. Шилова), компетентність з ІКТ (І. Зімняя, А. Маркова, А. Хуторський, С. Шишов,), інформатична компетентність (Н. Бібік, Н. Морзе, Л. Петухова, С. Смирнова-Трибульська).

Однак, вважаємо, що вживання терміну “інформатичний” є більш повним i змістовним щодо означення категорій у сфері інформатики й ІКТ. Введення i вживання словосполучень 3 терміном “інформаційні” у галузі практичної інформатики й породжених нею технологій призвело до вимивання сутнісного навантаження ключового слова, воно втратило свої чіткі смислові межі. Зокрема, абсолютно не проглядається обов'язкова змістова присутність у зазначених категоріях комп’ютерних засобів, оскільки абсолютизована перша (“інформація”) сутнісна складова терміну “інформатика” і проігнорована друга (“автоматика”) іiі складова. Адже до інформаційних технологій також відносять, зокрема, й засоби масової інформації - періодичну пресу, радіо, телебачення, - які існували ще до появи комп’ютерів. Тобто, термін “інформаційні” має два сутнісних значення, що вважається мовною хибою, є певним мовним недоліком терміну. У контексті зазначеного вище виправданим є використання терміну “інформатичний”. У цьому разі зберігається як сутнісне значення самого терміну (інформатика), так і лексика й морфологія української мови (інформатика - інформатичний). До того ж, зважаючи на те, що змістовим аналогом терміну “інформатичний” є взаємоуточнювальне словосполучення “комп”ютерно-інформаційний”, то для іменування відповідних категорій у сфері інформатики й інформаційно-комунікаційних технологій вдається зменшити кількість використовуваних слів [4].

Отже, вживання терміну “інформатичний” є більш повним і змістовним щодо означення категорій у сфері інформатики та IКT.

Інформатична компетентність - це інтегративне утворення особистості, яке інтегрує знання, про основні методи інформатики й інформаційних технологій, уміння використовувати наявні знання для розв'язання прикладних задач, навички використання комп'ютера і технологій зв'язку, здатності представляти повідомлення і дані у зрозумілій для всіх формі і виявляється у прагненні, здатності і готовності до ефективного застосування сучасних засобів інформаційних i комп'ютерних технологій для розв'язання завдань у професійній діяльності і повсякденному житті, 
усвідомлюючи водночас значущість предмета і результату діяльності [3, с. 66].

На наш погляд, цікавими є наробки Є. Смирнової-Трибульської, яка зауважує, що інформатичні компетентності вчителя формуються одночасно у двох напрямах: як користувача у галузі IКТ і як ефективного засобу для підвищення якості освіти [8, c. 211].

Петухова Л. С. розуміє інформатичні компетентності вчителів початкових класів як комплексну характеристику системи теоретичних і методичних предметноспеціальних знань, а також особистісних якостей педагога, що дозволяє йому ефективно здійснювати професійно-педагогічну діяльність. Водночас вона не зводиться до знань і вмінь роботи з комп'ютером, а передбачає необхідну обізнаність у сфері дидактики й теорії виховання. Компонентами інформатичних компетентностей учителя виступають умотивована професійна спрямованість, креативність мислення, здатність до рефлексії, потреба в самовдосконаленні тощо; вони акумулюють у собі інтеграцію досвіду, теоретичних знань, практичних умінь i значущих для педагога особистісних якостей [7, с. 190].

Деякі вчені досліджують інформаційну культуру вчителя, зокрема А. Коломієць визначає інформаційну культуру вчителя початкової школи як систему ціннісних орієнтацій, знань, умінь і навичок із формування потреби в інформації; iз здійснення пошуку необхідної інформації з усієї сукупності інформаційних ресурсів; з відбору, оцінювання, збереження знайденої інформації; з інтеграції, структуризації i створення нової інформації, презентації іï учням 3 урахуванням їхніх вікових особливостей; 3 використання інформаційних телекомунікаційних технологій, зокрема комп’ютерних дидактичних ігор, у навчально-виховному процесі початкової школи [5, с. 146].

Поняття “інформаційна культура” вчителя початкових класів є більш широким за обсягом ніж “інформатичні компетентності”, однак 3 погляду конкурентоспроможності майбутнього фахівця слід зосередити увагу саме на формуванні інформатичних компетентностей, які охоплюють компетентності в галузі інформаційних і комунікаційних технологій i передбачають здатність особи орієнтуватися в інформаційному просторі, володіти й оперувати інформацією відповідно до потреб ринку праці.

Отже, під інформатичними компетентностями майбутніх учителів початкової 
школи нами розуміється комплексна характеристика системи знань, умінь і навичок набуття і трансформації інформації в професійно-педагогічній діяльності, особистісні якості педагога, що в сукупності дозволяє йому ефективно здійснювати професійну діяльність з усвідомленим передбаченням іiі наслідків і постійним професійним саморозвитком.

Класифікація інформатичних компетентностей, розроблена Петуховою Л. С. [7, с. 183-184], включає основні засоби роботи, якими майбутній учитель має оволодіти для успішної реалізації компетентності з інформаційно-комунікаційних технологій у своїй професійній діяльності: інформатично-збиральна, інформатичноперетворювальна, інформатично-зберігаюча, інформатично-презентувальна, інформатично-мережева.

Інформатично-збиральна компетентність передбачає здатність до пошуку i накопичення даних за допомогою електронних словників, енциклопедій, журналів, книг, спілкування 3 фахівцями на спеціалізованих форумах $\mathrm{i}$ електронних конференціях.

Інформатично-перетворювальна компетентність передбачає здатність до аналізу, класифікації і систематизації отриманих даних, переведення їх у формат, придатний для розв’ язання певних завдань, зміни структури даних.

Наявність інформатично-зберігаючої компетентності забезпечує вміння вибору доцільного програмного забезпечення і створення оптимальної файлової структури для зручного зберігання і швидкого пошуку необхідної інформації, а також захисту даних.

Сформованість інформатично-презентувальної компетентності гарантує наявність уміння вибору необхідного програмного забезпечення для якнайкращого представлення інформації, навичок створення відповідних документів і публічного представлення.

Інформатично-мережева компетентність є сукупністю знань, умінь і навичок роботи в комп'ютерній мережі, сформованість культури спілкування в соціальних мережах, ефективних методів пошуку інформації, участі в форумах i on-line конференціях.

Основними педагогічними умовами формування інформатичних компетентностей майбутнього вчителя початкових класів сучасні дослідники 
визначають такі.

Нікулочкіна О. В. вказує на такі умови:

- диференційований підхід до розвитку інформаційної компетентності педагогів початкової ланки освіти;

- застосування інформаційно-комунікаційних технологій;

- оптимальне поєднання інноваційних форм і методів навчання з традиційними [6].

Коломієць А. М. виділяє педагогічні умови:

- створення у ВН3 інформаційного середовища для забезпечення максимального доступу до інформаційних ресурсів;

- застосування особистісно-орієнтованого, діяльнісного й інтегративного підходів до професійної підготовки майбутнього вчителя початкових класів;

- створення умов для творчої інформаційної діяльності;

- вивчення студентами продуктів комп'ютерно-освітньої і комп'ютерно-ігрової індустрії [5].

Петухова Л. Є., крім створення інформаційно-комунікаційного педагогічного середовища, виокремлює систему умов:

- адаптація змісту професійної підготовки майбутніх учителів початкової школи відповідно до сучасних вимог;

- раціональне поєднання традиційних і комп'ютерних технологій навчання й активізація навчально-пізнавальної діяльності студентів;

- посилення мотивації й інтересу студентів до набуття знань;

- формування професійних умінь i навичок на основі розвитку творчого педагогічного мислення студентів;

- залучення їх до продуктивної науково-дослідної роботи;

- використання засобів гіпертекстових, мультимедійних і дистанційних технологій як платформи побудови сучасної комп’ютерно-орієнтованої педагогічної системи навчання;

- врахування особливостей і прагнень студентів, орієнтованих на індивідуальні освітні програми;

- систематичний i оперативний контроль і корекція результатів навчальної діяльності студентів [7]. 
Отже, завданням викладачів і керівництва вищих педагогічних навчальних закладів є забезпечення студентів, крім традиційних знань, умінь і навичок, умовами для формування необхідних методичних компетентностей щодо застосування IКТ у практичній діяльності: створення у ВН3 інформаційно-комунікаційного педагогічного середовища, раціональне поєднання традиційних й інформаційнокомунікаційних технологій навчання, навчально-методичне забезпечення процесу формування інформатичних компетентностей, посилення мотивації й інтересу студентів до набуття знань і професійних умінь, застосування диференційованого, діяльнісного і модульного підходів, систематичний і оперативний контроль і корекція результатів.

Завершальною фазою підготовки майбутніх вчителів і перевіркою ступеня їх підготовленості до використання ІКТ є практична реалізація набутих знань, навичок i вмінь під час проведення навчальних занять. Тим самим підготовка вчителів отримує свою логічну завершеність [1, с. 73; 9]. Одним із найдієвіших інструментів у цьому випадку О. В. Суховірський вважає педагогічну практику. Саме аналіз діяльності, максимально наближеної до умов майбутньої професії, вказує на ефективність підготовки вчителя. Під час педагогічної практики відбувається професійна адаптація студентів.

Практика належить до квазіпрофесійної діяльності, яку вчені в умовах професійної підготовки майбутніх фахівців трактують як форму, метод i засіб навчання.

Квазіпрофесійні тренінги, імітаційні, рольові й ділові ігри дають змогу студентам чіткіше уявити знання про майбутню професійну діяльність у найзручнішому для засвоєння вигляді. Теоретико-методологічні основи такого навчання продукуються й розвиваються у межах контекстного підходу, суть якого, за А. Вербицьким, полягає в активному навчанні, спрямованому на реалізацію системного використання професійного контексту, тобто поступового насичення навчального процесу елементами професійної діяльності [2].

Отже, квазіпрофесійна діяльність майбутнього вчителя початкових класів - це професійна за змістом і навчальна за формою реалізації через рольові і проектні методики моделювання педагогічна діяльність, що формує й удосконалює методичні вміння майбутнього вчителя i стимулює його до самоаналізу i професійного 
самовдосконалення.

Ми вважаємо необхідним наголосити на тому, що перед початком педагогічної практики студенти повинні знати методику застосування IКТ в початковій школі, санітарно-гігієнічні норми, фізіологічні і психологічні особливості дітей молодшого шкільного віку, володіти уміннями варіювати прояви інформатичної компетентності в умовах рівня комп’ютеризації школи, знати рівні інформатизації діяльності вчителів і методику їх визначення тощо. П. М. Щербань вказує, що підготовка до педагогічної практики відбувається значно успішніше, якщо студент - майбутній учитель, уже в роки навчання в університеті поставлений в умови, наближені до його майбутньої професійної діяльності. Це стає можливим, якщо використовувати педагогічну гру, яка є груповою вправою з вироблення оптимальних рішень, застосування навчальних методів і прийомів у штучно створених умовах, що відтворюють реальну обстановку на заняттях у школі $[12$, с. 5]. Так, Ж. С. Фрицко вбачає початок перенесення теоретичних знань у практичну діяльність задовго до виходу студентів на педагогічну практику. Цю тезу автор підтверджує тим фактом, що на сучасному етапі розвитку системи професійної підготовки найбільш поширений іï варіант є такий: теоретична підготовка - моделювання - педагогічна практика - рефлексія - наставництво [11].

Серед студентів Херсонського державного університету спеціальності «Початкова освіта» було проведено анкетування 3 метою дослідити рівень i можливості користування Інтернетом студентами, планування i можливості застосування IКT під час практики. Загальна кількість респондентів становить 282 особи.

Необхідність знання Інтернету й роботи 3 комп'ютером для майбутньої професії визначили 64,2\% студентів, 35\% - частково й 0,7\% вважають їх зовсім не потрібними. Результати відповідей респондентів свідчать про усвідомлення необхідності комп’ютерної грамотності в діяльності вчителя початкових класів.

Щодо використання комп’ютерних технологій і Інтернету в роботі з молодшим школярем студенти за результатами анкетування висловили такі думки: 7,1\% - не потрібно, бо шкідливо; 79,8\% - у деяких випадках; 13,1\% - потрібно завжди. Отже, результати свідчать, що майбутні вчителі початкової школи розуміють шкідливість використання комп'ютерної техніки 3 дітьми, однак усвідомлюють, що це $\epsilon$ необхідним і невідворотним. 
Серед умов, що стимулюють до використання IKT в майбутній педагогічній діяльності респондентами визначено: 20,9\% - можливість роботи в комп'ютерному класі ВНЗ, 38,3\% - доступ до мережі Інтернет у ВНЗ, 50,7\% - творчі завдання 3 методик початкової освіти, 17\% - проходження практики у школі з комп'ютерним забезпеченням.

Необхідними умовами для професійного зростання студентів у сфері IКТ визначено: 61\% - підвищення рівня комп'ютерної грамотності, 30,5\% - вивчення методики і правил роботи молодшого школяра з IKT, 31,9\% - орієнтування у сучасних тенденція інформатизації освіти. Отже, крім доступу до мережі Інтернет, майбутні вчителі початкових класів необхідними умовами професійної підготовки до використання ІКТ вважають виконання творчих професійно спрямованих завдань, отримання необхідного досвіду під час проходження педагогічної практики, підвищення рівня комп'ютерної грамотності, оволодіння необхідними знаннями й уміннями забезпечення інформаційно-комунікаційного педагогічного середовища в початковій школі.

За результатами анкетування 63,8\% студентів планує використовувати IКТ під час проходження практики в школі, 29,8\% - сумніваються у відповіді, а 6,4\% - взагалі не планують будь-яке застосування IКТ в практичній діяльності.

Серед можливостей застосування IКТ під час практики студенти вказують: 71,3\% - оформлення звітної документації, 47,2\% - створення дидактичного матеріалу, 43,6\% - показ учням різнопланових презентацій, 20,6\% - підбір програмного забезпечення навчально-ігрового характеру, 4\% - електронне консультування 3 керівниками від бази практики та ВНЗ. Результати свідчать про досить високий i різносторонній рівень підготовки майбутніх учителів до використання IКТ у практичній діяльності.

Висновки 3 даного дослідження i перспективи подальших розвідок у даному напрямку. Формування інформатичних компетентностей - це складний систематичний цілеспрямований процес підготовки майбутніх фахівців до професійної діяльності в умовах інформаційного суспільства. Головними педагогічними умовами забезпечення цього процесу $є$ : створення у ВНЗ інформаційно-комунікаційного педагогічного середовища, раціональне поєднання традиційних і інформаційно-комунікаційних технологій навчання, навчально- 
методичне забезпечення процесу формування інформатичних компетентностей, посилення мотивації й інтересу студентів до набуття знань і професійних умінь, застосування диференційованого, діяльнісного і модульного підходів, систематичний і оперативний контроль і корекція результатів.

Практичній спрямованості інформатичних компетентностей сприяє квазіпрофесійна діяльність майбутніх учителів початкових класів. Основними формами іiі реалізації $є$ імітаційне моделювання й педагогічна практика. Однак формування інформатичних компетентностей, на нашу думку, має розпочатися до практики в школі на етапі інтенсифікації.

Подальшого дослідження потребує змістове і навчально-методичне наповнення процесу формування інформатичних компетентностей студентів - майбутніх учителів початкових класів у квазіпрофесійній діяльності.

\section{Список використаних джерел}

1. Беспалов П. В. Компьютерная компетентность в контексте личностноориентированного обучения /Беспалов П. В. // Педагогика. - 2003. - № 4. - С. 45-50.

2. Вербицкий A. А. Активное обучение в высшей школе: контекстный подход / А. А. Вербицкий. - М. : Высшая школа, 1991. - 208 с.

3. Головань M. Інформатична компетентність: сутність, структура та становлення / М. Головань // Інформатика та інформаційні технології в навчальних закладах. - 2007. - № 4. - С. 62-69.

4. Дорошенко Ю. О. Інформатика: еволюція поняття // Міжнародна науковопрактична конференція інформатизація освіти України: європейський вимір [Електронний ресурс]. - Режим доступу : http://labconf.ic.km.ua/tezy/docs/71.pdf.

5. Коломієць A. М. Інформаційна культура вчителя початкових класів : дис. ... доктора пед. наук / Коломієць А. М. - К., 2008. - 526 с.

6. Нікулочкіна $O$. B. Розвиток інформаційної компетентності вчителя початкових класів у системі післядипломної освіти : дис. ... канд. пед. наук : 13.00.04 / Нікулочкіна Олена Василівна. - Запоріжжя, 2009. - 278 с.

7. Петухова Л. $Є$. Теоретико-методичні засади формування інформатичних компетентностей майбутніх учителів початкових класів : дис. ... доктора пед. наук / Петухова Л. С. - Херсон, 2009. - 564 с.

8. Смирнова-Трибульска $C$. М. Теоретико-методичні основи формування 
інформатичних компетентностей вчителів природничих дисциплін у галузі дистанційного навчання : автореф. дис. на здобуття наук. ступеня доктора пед. наук : 13.00.02 / Смирнова-Трибульска Є. М. - К., 2008. - 44 с.

9. Суховірський О. В. Підготовка майбутнього вчителя початкової школи до використання інформаційних технологій: дис. ... канд. пед. наук : 13.00 .04 / Суховірський О. В. - К., 2005. - 303 с.

10. Урсова О. В. Развивающий потенциал информационно-коммуникационных технологий в системе повышения квалификации учителей-предметников : дис. ... канд. пед. наук : 13.00.08 / Урсова О. В. - Великий Новгород, 2006. - 195 с.

11. Фрищко Ж. С. Квазипрофессиональная деятельность при подготовке будущих учителей в условиях педагогического колледжа [Електронний ресурс] / Ж. С. Фрицко // Интернет-журнал «Эйдос». - 2007. - 30 сентября. - Режим доступу до журн. : http:www.eidos.ru/journal/2007/0930-24.htm.

12. Щербань П. М. Активні методи підготовки майбутніх учителів / П. М. Щербань. - К. : Т-во “Знання” УРСР, 1988. - 48 с.

\section{ПЕДАГОГИЧЕСКИЕ УСЛОВИЯ ФОРМИРОВАНИЯ ИНФОРМАТИЧЕСКИХ КОМПЕТЕНТНОСТЕЙ СТУДЕНТОВ - БУДУЩИХ УЧИТЕЛЕЙ} НАЧАЛЬНЫХ КЛАССОВ

Коткова Вера Владимировна, аспирант кафедры педагогики и психологии Херсонского государственного университета, г. Херсон

\section{Аннотация}

Актуальность статьи обусловлена современной потребностью информационного общества в подготовке информатически компетентных специалистов начального образования. В статье обобщены педагогические условия обеспечения процесса формирования информатических компетентностей студентов на основе современных научных исследований, определено место квазипрофессиональной деятельности студентов в процессе становления информатических компетентностей. Автор статьи обобщает результаты анкетирования с целью исследования уровня и возможности пользования Интернет студентами, планирование и характер применения ИКТ во время практики. Среди педагогических условий формирования информатических компетентностей будущих учителей начальных классов выделено квазипрофессиональную деятельность, 
основными формами реализации которой является имитационное моделирование и педагогическая практика.

Ключевые слова: информатические компетентности, квазипрофессиональная деятельность, этапы интенсификации и идентификации, контекстное обучение.

\section{PEDAGOGICAL CONDITIONS OF INFORMATIVE COMPETENCIES} FORMATION OF STUDENTS - FUTURE PRIMARY SCHOOL TEACHERS

Vira V. Kotkova, postgraduate of Pedagogy and Psychology Chair, Kherson State University, Kherson

\section{Resume}

The article is actual due to the current informative society needs in informatively competent professionals of primary education. The author generalizes the pedagogical conditions of forming students' informative competencies based on modern scientific researches. The place of students' quasiprofessional activity in perfection of informative competencies is defined. The author of the article summarizes the results of questionnaires, which purpose is to investigate students' capabilities and the level of Internet use, planning and kind of information and communication technologies use during their practice in primary school. Quasiprofessional activity, which main forms of realization are simulation and pedagogical practice, is singled out among pedagogical conditions of forming future primary school teachers' informative competencies.

Keywords: informative competencies, quasiprofessional activity, phases of intensification and identification, contextual learning.

Матеріал надійшов до редакції 31.03.2011 p. 